\title{
Plasma rico en plaquetas
}

\author{
Platelet -rich plasma
}

\section{J. González Lagunas}

Resumen: El Plasma Rico en Plaquetas es una suspensión concentrada de la sangre centrifugada que contiene elevadas concentraciones de trombocitos. Durante los últimos años, este producto ha aparecido de forma repetida en publicaciones científicas y en medios de comunicación generales como un producto que por sus características induce la curación y regeneración de los tejidos. La premisa de su uso es que las elevadas concentraciones de plaquetas en el PRP, liberan cantidades significativas de factores de crecimiento. En este artículo se van a recoger las evidencias científicas que se han presentado en la literatura médica con respecto al PRP y a la curación ósea, así como las diferentes aplicaciones clínicas que se han sugerido.

Palabras clave: Plasma rico en plaquetas; Osteoinducción; Injerto óseo; Regeración ósea.

Recibido: 25.02 .2005

Aceptado: 09.03.2005
Abstract: Platelet-rich plasma is a by-product of centrifuged whole blood that contains high levels of thrombocytes. In the last decade, scientific and media interest has been generated by this product that apparently has the capacity of inducing and promoting tissue healing and regeneration. The premise of its use is that the large number of platelets in PRP release significant amounts of growth factors. In this paper, a critical review of the medical literature regarding PRP and bone healing will be presented. Also, the suggested clinical applications of the product will be addressed.

Key words: Platelet-rich plasma; Osteoinduction; Bone regeneration; Bone graft.

Médico Especialista.

Servicio de Cirugía Oral y Maxilofacial.

Hospital Universitari Vall d'Hebrón, Barcelona, España

Correspondencia:

Casanova 101 Principal

08011 Barcelona, España

E-mail: glagunas@terra.es 


\section{Introducción}

El Plasma Rico en Plaquetas o Plasma Rico en Factores de Crecimiento es una suspensión concentrada de la sangre centrifugada que contiene elevadas concentraciones de trombocitos. Durante los últimos años, este producto ha aparecido de forma repetida en publicaciones científicas y en medios de comunicación generales como un producto que por sus características induce la curación y regeneración de los tejidos. A pesar del entusiasmo que ha despertado el desarrollo del producto entre algunos autores y la difusión que han realizado las empresas que comercializan los kits de obtención del PRP, siguen existiendo dudas sobre la verdadera eficacia del Plasma Rico en Plaquetas sobre la regeneración esquelética. En este artículo se van a recoger las evidencias científicas que se han presentado en la literatura médica con respecto al PRP y a la curación ósea

\section{Fundamentos}

Las plaquetas contienen cierto número de factores de crecimiento.

Los factores de crecimiento son proteinas que desempeñan un papel esencial en la migración, diferenciación y proliferación celular. Se han descrito un gran número de estas proteínas, pero en el tema que nos ocupa los más importantes son PDGF (Growth factor derived from platelets) TGF-B (Transformed beta growth factor), FGF (Fibroblast growth factor), VEGF. (Vascular endothelial growth factor), e IGF (Insulin-Growth factor). ${ }^{1}$

Los factores de crecimiento tienen un elevado coste económico, y son necesarias dosis repetidas para conseguir un efecto terapéutico clínicamente evidente. ${ }^{1}$ Por este motivo, la hipótesis de trabajo que ha conducido al desarrollo del PRP es que en un producto con mayor concentración de plaquetas, los niveles de factor de crecimiento aumentarían en relación lineal con el número de plaquetas. ${ }^{2}$ La producción de este gel permitiría una liberación sostenida de los factores de crecimiento.

Con este concepto in mente, la industria ha lanzado al mercado unos sistemas diseñados específicamente para la preparación rápida de concentrado de plaquetas a partir de una pequeña muestra de sangre (Tabla I). Supuestamente, permitirían la concentración de los factores de crecimiento naturales que se encuentran en las plaquetas. Estos sistemas deben cumplir los

\section{Introduction}

Platelet-Rich Plasma or Plasma Rich in Growth Factors is a concentrated suspension from blood placed in a centrifuge machine and spun down, that contains high levels of thrombocytes. During the last few years, this product has appeared repeatedly in scientific publications and in the general media as a product that, due to its characteristics, enhances healing and tissue regeneration. In spite of the enthusiasm generated in some authors by the development of the product and the diffusion carried out by the companies that market the kits for obtaining PRP, there are still doubts as to the true effectiveness of platelet-rich plasma on skeletal regeneration. This article will gather together the scientific evidence presented in the medical literature with regard to PRP and bone healing.

\section{Foundations}

Platelets contain a certain number of growth factors. Growth factors are proteins that play an essential role in celIular migration, differentiation and proliferation. A large number of these proteins have been described but, in the subject that concerns us, the most important are PDGF (Plateletderived growth factor) TGF- $b$ (Transforming growth factor beta), FGF (Fibroblast growth factor), VEGF (Vascular endothelial growth factor), and IGF (Insulin-like growth factor). ${ }^{1}$

Growth factors are costly, and repeated doses are required in order to achieve a therapeutic effect that is clinically evident. ${ }^{1}$ For this reason, the work hypothesis that has led to the development of PRP is that, with a product having a larger concentration of platelets, the growth factor levels increase linearly according to the number of platelets. ${ }^{2}$ The production of this gel allows a sustained release of growth factors.

With this concept in mind, the industry has launched onto the market systems designed specifically for the rapid preparation of platelet concentrate from a small sample of blood (Table 1). This supposedly permits the concentration 


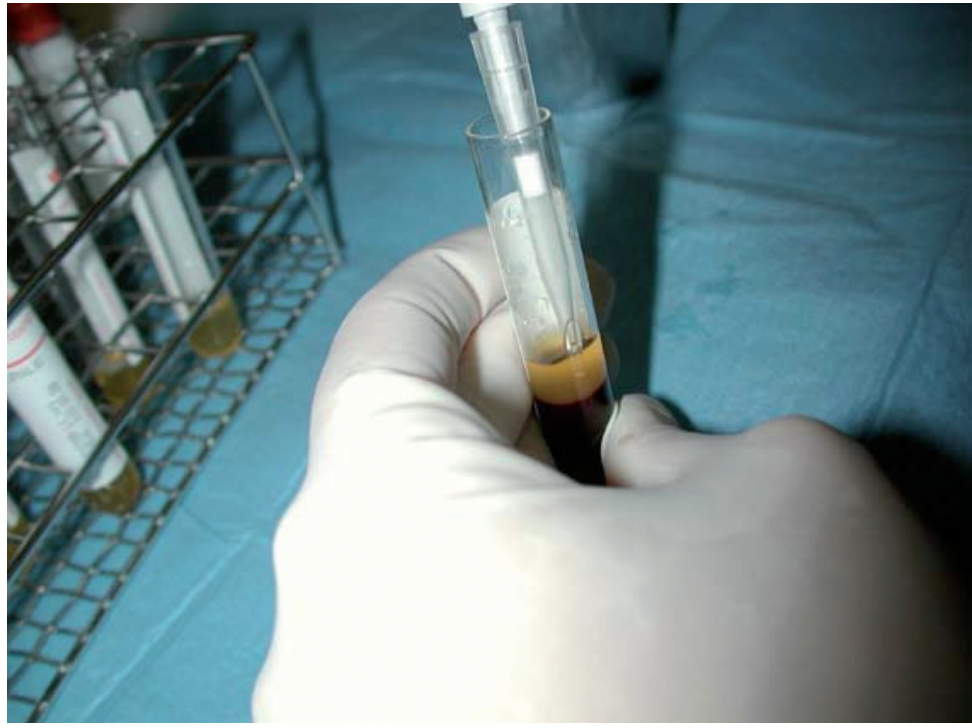

Figura 1. Pipeteado de la muestra hemática cenrifugada.

Figure 1. Pipetting after centrifugation of blood sample.

siguientes requisitos: ser viables en la práctica ambulatoria, concentrar las plaquetas entre 3-6 veces sus niveles basales, retener y preservar plaquetas viables y liberar factores de crecimiento durante 7-10 días. ${ }^{2}$ Los estudios comparativos presentados no revelan diferencias significativas en los resultados obtenidos con los diferentes sistemas. ${ }^{3-5}$

\section{Antecedentes históricos}

En 1994, un grupo de cirujanos empleó la adición de un adhesivo de fibrina autógena al hueso esponjoso durante la reconstrucción mandibular. ${ }^{6}$ Para ello recurrieron a la separación de una muestra de sangre en sus componentes y emplearon la fracción plasmática como crioprecipitado. Observaron una consolidación ósea precoz, que se atribuyó al mayor número de células osteocompetentes que quedaban en la red de fibrina. En 1997, Whitman presentó el gel de plaquetas como alternativa autóloga al adhesivo de fibrina en cirugía oral y maxilofacial, utilizándolo no sólo como adhesivo tisular sino también como procedimiento para la consolidación inicial de injertos córtico-esponjosos en los maxilares. ${ }^{7}$ Más adelante, Marx y cols, ${ }^{8}$ observaron que el PRP aumentaba la concentración de plaquetas en los injertos, observándose la presencia de, al menos 3 factores de crecimiento: PDGF, TGF-ß1 y 2. Vieron que las células esponjosas tenían receptores para estos factores de crecimiento. Su evaluación de la ortopantomografia y la histomofometría concluyó que:

1. La adición de PRP aceleraba la velocidad de formación ósea y el grado de formación ósea durante al menos 6 meses.

2. Era técnicamente posible secuestrar, concentrar y añadir un mayor número de plaquetas (y en consecuencia de factores de crecimiento) a los injertos óseos.

3. Las stem-cells de la médula esponjosa contenían receptores para los factores de crecimiento. of the natural growth factors that are to be found in platelets. These systems should comply with the following requirements: they should be viable on an outpatient basis, they should concentrate the platelets between 3-6 times their basic levels, and they should be able to retain and preserve viable platelets and release growth factors for 7-10 days. ${ }^{2}$ The comparative studies presented do not reveal any significant differences in the results obtained with the different systems. ${ }^{3-5}$

\section{Historical antecedents}

In 1994, a group of surgeons added an autologous fibrin adhesive to cancellous bone in mandibular reconstruction. ${ }^{6}$ For this they resorted to separating a blood sample into its components and they used the plasma fraction as cryoprecipitate. They observed early bone consolidation that was attributed to the larger number of osteo-competent cells that remained in the fibrin mesh. In 1997 Whitman presented the platelet gel as an autologous alternative to the fibrin adhesive for oral and maxillofacial surgery, using it not only as a tissue adhesive but also as a means of initiating the consolidation process of corticocancellous grafts in the maxillas. ${ }^{7}$ Later on, Marx and cols observed that PRP increased the concentration of platelets in the grafts, and they observed the presence of at least 3 growth factors: PDGF, TGF- $\beta 1$ and 2. They observed that spongy cells had receptors for these growth factors. Their evaluation in orthopantomographies and histomorphometries concluded that:

1. Adding PRP increased the speed at which bone was formed and the degree of bone formation during at least 6 months.

2. It was technically possible to, concentrate and add a large number of platelets (and as a result growth factors) to bone grafts.

3. Stem-cells from spongy [bone] marrow contained receptors for growth factors.

\section{Proposed indications for Platelet-rich plasma}

Not confusing the actions of growth factors or BMP with the actions of Platelet-rich plasma is fundamental.2,6,9,10 It is also important to point out that in some of these potential applications, there is no consistent evidence as to its longterm efficiency, although the clinical "appreciation" of the authors would indicate that there are some benefits associated with its use:

1. Bone growth and maturation.

2. Graft stabilization.

3. Wound sealing (flap attachment).

4. Scar formation (soft tissue regeneration).

5. Hemostasia (cessation of capillary bleeding and potential haematomas). 


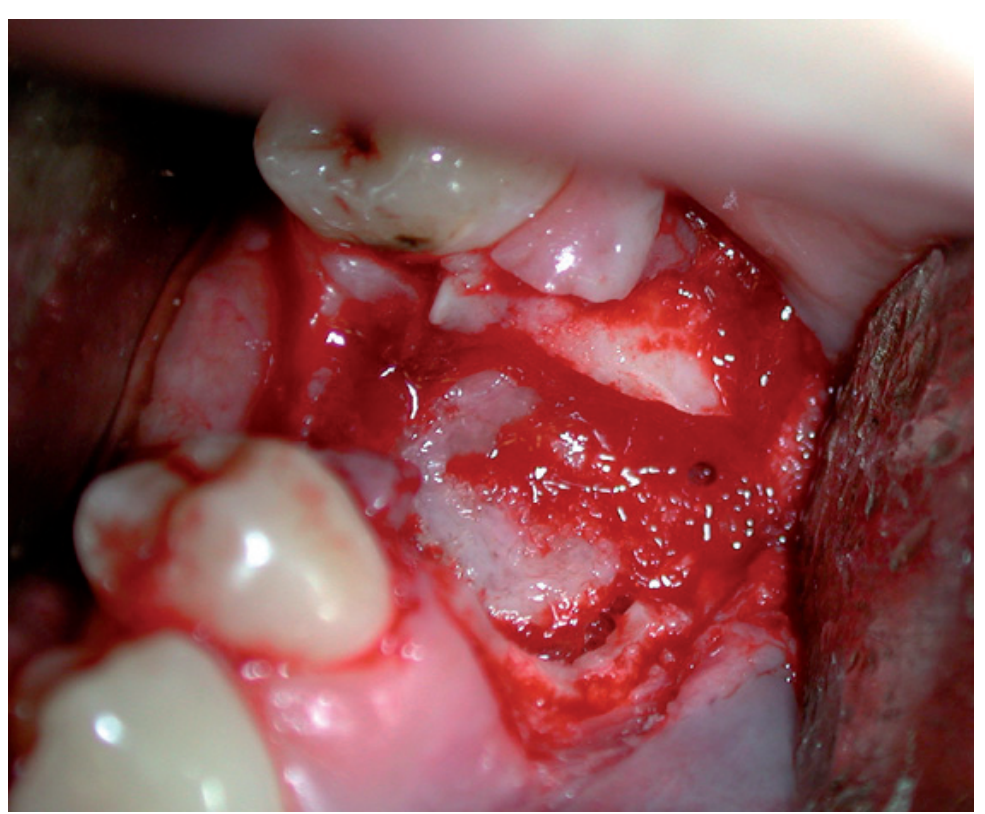

Figura 2. Cavidad de extracción rellena con con Bio-Oss y PRP.

Figure 2. Extraction cavity filled with Bio-Oss and PRP.

\section{Indicaciones propuestas para el plasma rico en plaquetas}

Es fundamental no confundir las acciones de los factores de crecimiento o de las BMP con las acciones del Plasma Rico en Plaquetas. 2,6,9,10 También es importante indicar que en algunas de estas aplicaciones potenciales, no existen evidencias consistentes sobre su eficacia a largo plazo, aunque la "apreciación" clínica de los autores señala algunos beneficios relacionados con su uso:

1. Crecimiento y maduración ósea.

2. Estabilización de injertos.

3. Sellado de heridas (aproximación de colgajos).

4. Cicatrización de heridas (regeneración de tejidos blandos).

5. Hemostasia (detención del sangrado capilar y de potenciales hematomas.

6. Implantología.

7. Otras aplicaciones:

a. Traumatología y ortopedia: lesiones óseas y de tejidos blandos. b.Transportador de fármacos.

\section{Estudios sobre regeneración ósea en animales}

La hipótesis de trabajo de la mayor parte de los estudios presentados es que la adición de PRP a un material de injerto autógeno o alogénico tiene un efecto positivo sobre la cicatrización ósea. Este efecto se debe evaluar con parámetros objetivables como son estudios radiológicos, histológicos e histomorfométricos.

Fennis, 11-12 ha presentado dos estudios sobre cabras en las que practicó una resección mandibular que se reconstruyó con hueso iliaco particulado con y sin PRP. La evaluación radiológica, histológica e histomorfométrica reveló que el uso del PRP mejoraba considerablemente la curación ósea a las 6 y 12 semanas.
6. Implantology.

7. Other applications.

a. Traumatology and orthopedics: bone and soft tissue lesions.

b. Medication carrier.

\section{Bone regeneration studies on animals}

The study hypothesis of most of the papers presented is that the addition of PRP to an autogenous or allogenic graft material has a positive effect on bone healing. This effect should be evaluated with objective parameters such as with radiologic, histologic and histomorphometric examination.

Fennis 11,12 presented two studies on goats that underwent mandibular resection and reconstruction with particulate bone from the iliac crest with and without PRP. The radiologic, histologic and histomorphometric studies revealed that the use of PRP considerably improved bone healing at 6 to 12 weeks.

Aghaloo and cols carried out studies on parietal rabbit bone, grafting surgical defects with autogenous bone, PRP or a combination of both. Radiographic, histologic and histomorphometric analysis permitted the observation of a slight tendency towards a greater bone density with the addition of PRP that without it. However, the differences were not statistically significant. ${ }^{13}$ In another similar study, but with demineralised bovine bone, better bone density was observed in the cases grafted with autogenous bone, than in those grafted with demineralised bovine bone and PRP. ${ }^{14}$

A canine study compared bone healing in mandibular resection defects reconstructed with isolated autogenous bone, or combined with PRP. The biopsies at 6 weeks and fluorescence microscopy revealed that PRP did not enhance new bone formation. ${ }^{15}$

Kim carried out a study placing titanium implants in the iliac crest of dogs, and filling the peri-implant defects with a combination of dentine/plaster of Paris, with and without PRP. According to the authors, osteointegration improved in the dogs treated with PRP. ${ }^{16}$ In another canine study in which demineralised bone powder was used, Kim studied osteointegration of dental implants in the iliac crest, observing that there was better osseous contact when the bone was combined with PRP. ${ }^{17}$ Furthermore, the three works mentioned are difficult to apply in customary clinical situations, given that the implants were applied on external oral cavity bone, where the bacterial contamination conditions are different.

In a study on 28 rats Winstar, Roldan and cols ${ }^{18}$ observed that the application of PRP did not enhance the formation of bone in anorganic bovine bone nor in autogenous bone grafts. In another study on porcine frontal skull bones, the preparation of the graft bed with PRP does not appear to have had any influence on the osteointegration of implants. ${ }^{19}$ Zechner, on the other hand created mandibular defects in 12 minipigs, applying PRP and placing implants He observed 


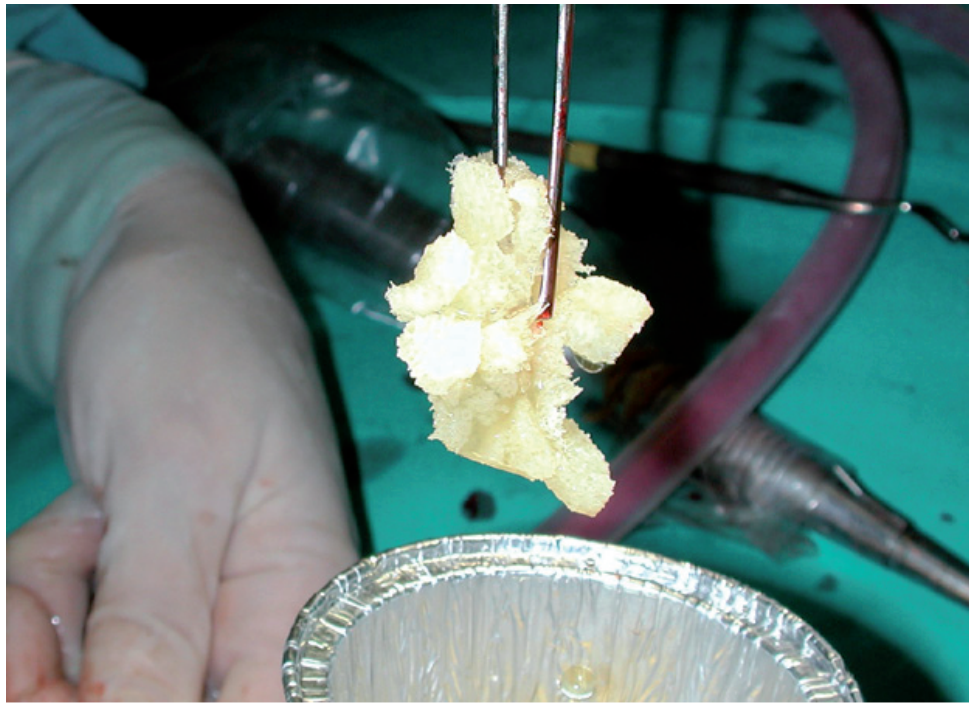

Figura 3. Hueso heterólogo mezclado con PRP.

Figure 3. Heterologous bone mixed with PRP.

Aghaloo y cols., efectuaron un estudio sobre hueso parietal de conejo injertando un defecto quirúrgico con hueso autógeno, PRP o una combinación de ambos. Un análisis radiográfico, histológico e histomorfométrico permitió observar una ligera tendencia a mayor densidad de hueso con la adición de PRP que sin él. Sin embargo, las diferencias no fueron estadísticamente significativas. ${ }^{13}$ En otro estudio similar pero con hueso bovino desmineralizado se observó una mejor densidad ósea en los casos injertados con hueso autógeno, que en aquellos injertados con hueso bovino desmineralizado y PRP. ${ }^{14}$

Un estudio en perros compara la curación ósea de un defecto de resección mandibular reconstruido con hueso autógeno aislado, o combinado con PRP. Las biopsias a las 6 semanas y la microscopía por florescencia revelaron que el PRP no mejoró la neoformación ósea. ${ }^{15}$

Kim efectuó un estudio colocando implantes de titanio en la cresta iliaca de perros, y rellenando defectos peri-implantarios con una combinación de dentina/yeso Paris, con y sin PRP. Según los autores la osteointegración mejoraba en los perros tratados con PRP. ${ }^{16} \mathrm{Kim}$ en otro estudio en perros utilizando polvo de hueso desmineralizado estudió la osteointegración de los implantes dentales en cresta iliaca, observando mejor contacto óseo cuando el hueso se combinaba con PRP. ${ }^{17}$ Los tres trabajos mencionados son además dificilmente aplicables a la situación clínica habitual, dado que se aplican los implantes en hueso externo a la cavidad oral, donde las condiciones de contaminación bacteriana son diferentes.

En un estudio sobre 28 ratas Winstar, Roldan y cols..$^{18}$ observaron que la aplicación de PRP no potenciaba la formación de hueso en hueso inorgánico bovino ni en injertos de hueso autógeno. En otro estudio sobre el hueso frontal de cerdos, la preparación del lecho del injerto con PRP no parece tener influencia sobre la osteointegración de implantes. ${ }^{19}$ Zechner, en cambio, crea defectos mandibulares en doce cerdos enanos, aplica PRP e instala implantes, observando una mejor regeneración ósea peri-implantaria en improved peri-implant bone regeneration in the initial phases (6 weeks), with the stimulation of osteogenic cell proliferation being comparable at 12 weeks. ${ }^{20}$

Lastly, in one of the few in vitro studies presented, ${ }^{21}$ the stimulation is studied of cell proliferation in the bone marrow of rats. Effects comparable with BMP could not be demonstrated.

Only the study by Fennis had study conditions comparable to those that are usually [found] when using PRP in oral and maxillofacial surgery, together with a rigorous analysis of the results. 11,12 His results suggest that there is a supposed beneficial effect of PRP when added to an autologous graft in goats. The authors recognise that they lack information on the PRP dose-effect relationship, as well as of the time period during which activity is shown.

\section{Application in dentoalveolar surgery}

A Spanish study presented alveolar healing experiences with and without platelet-rich plasma. The study was based on 10 patients with only 3 "split-mouth" design patients. Epithelialization was evaluated by means of a periodontal probe with photographs, and bone healing was evaluated with a biopsy at 4 weeks. The bone characteristics at 4 weeks were better in the PRP group that in the control [group]. ${ }^{22,23}$

Recently PRP has been analysed for preventing dry socket after the extraction of third molars. A prospective study was carried out on 118 patients, that underwent the Harvest system. Improved hemostasis was observed, the flap had a better appearance, there was less pain according to the visual analogue scale, and there was reduced incidence of dry socket (3.4 versus $12.5 \%$ ). It should however be pointed out that the evaluation was with non-quantifiable parameters. ${ }^{24}$

Della Valle et a ${ }^{25}$ applied PRP gel in 40 patients submitted to oral surgery and anticoagulant therapies requiring mechanical heart valve replacement: $5 \%$ reported hemorrhagic complications and $40 \%$ had mild bleeding that was treated with local hemostatic agents.

\section{Application in periodontics}

Its use in periodontics is basically of a clinical nature, although there are some works of investigation in biological science. Okuda and Kawase again demonstrated the high concentration of PDGF and TGF-beta in PRP, and they observed stimulation in the ADN synthesis in gingival fibroblasts and in periodontal ligament cells, as well as its capacity for regulating collagen synthesis in the extracellular matrix. ${ }^{26,27}$

De Obarrio incorporates PRP into a bone allograft combined with guided tissue regeneration techniques (GTR) in order to treat intrabony defects, observing a significant 


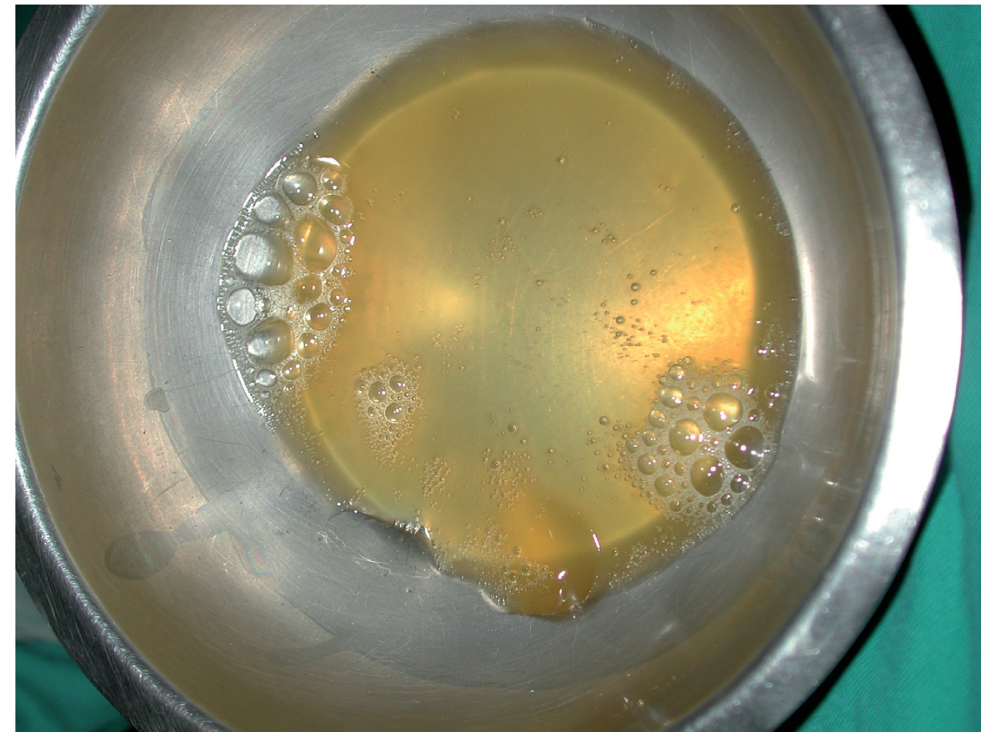

Figura 4.

Figure 4.

las fases iniciales ( 6 semanas), igualándose a las 12 semanas, ${ }^{20}$ la estimulación de la proliferación celular osteogénica.

Por último, en uno de los pocos estudios in vitro presentados, ${ }^{21}$ se estudia la estimulación de la proliferación celular en la médula ósea de ratas. No se pudo demostrar efectos comparables con el BMP.

Solamente, el estudio de Fennis presenta unas condiciones de trabajo comparables a las habituales del empleo de PRP en cirugía oral y maxilofacial, así como un análisis riguroso de los resultados.11,12 Sus resultados sugieren el supuesto efecto beneficioso del PRP cuando se añade a un injerto autólogo en cabras. Los autores reconocen que les falta información sobre la relación dosis-efecto del PRP, así como del periodo de tiempo durante el que muestra actividad.

\section{Aplicaciones en cirugía dentoalveolar}

Un estudio español presentó su experiencia con la curación alveolar con y sin Plasma Rico en Plaquetas. El estudio se efectuó sobre 10 pacientes, solamente 3 pacientes con diseño de "split-mouth". Se evaluó la epitelización con sonda periodontal y con fotografías, y se evaluó la curación ósea con biopsia a 4 semanas. Las carácterísticas óseas a las 4 semanas fueron mejores en el grupo PRP que en el control.22,23

Recientemente se ha analizado el PRP como prevención de la alveolitis seca después de la exodoncia de terceros molares Se trata de un estudio prospectivo sobre 118 pacientes, en los que se emplea el procedimiento Harvest. Observaron una mejor hemostasia, un mejor aspecto del colgajo, menor dolor según escala analogo-visual, y una menor incidencia de alveolitis seca ( 3,4 versus $12,5 \%)$. Se debe señalar, sin embargo, que la evaluación es con parámetros no cuantificables. ${ }^{24}$ increase in clinical attachment and bone fill in tests two year later. ${ }^{28}$

Various other studies have used PRP or fibrin gel for managing gingival recession defects. ${ }^{29-32}$ either on its own or combined with different techniques of guided bone regeneration and with different biomaterials. The authors themselves suggest that new studies are necessary in order to establish the role played by each component in these combined therapies.

\section{Application in sinus augmentation}

The application of PRP in sinus augmentation derives from its adhesive effect on grafted material. It has not been reliably demonstrated that it has an intrinsic osteoinductive effect on synthetic biomaterials. The literature contains just a few series that mainly include "How I do it" but no consistent results in the long term. ${ }^{33-37}$

Wallace and Froum presented in 2003 a systematic review of the literature with regard to implant survival in patients that had undergone sinus augmentation. They did not find sufficient data to be able to recommend the use of platelet-rich plasma in sinus augmentation..$^{38}$

In sinus augmentation with autogenous bone and PRP, Jakse et al observed an improvement of 3-4\% in bone formation in a study on 12 sheep. This difference was considered clinically as insignificant and they affirmed that [the results] "show a regenerative capacity of PRP of low poten$c y$ "In a study on 21 rabbits that underwent sinus augmentation with iliac crest, Butterfield obtained similar results, ${ }^{39}$ concluding that they could not find a stimulatory effect of PRP on autogenous bone grafts.

In sinus augmentation with demineralised bovine bone and PRP on 12 minipigs, Fürst concluded that the combination of PRP with other biomaterials was not demonstratively superior than PRP on its own. 40

There are also various studies on bone augmentation with biomaterials in humans. Froum carried out a study on 3 patients performing a bilateral sinus augmentation (demineralised bovine bone versus demineralised bovine bone with PRP). ${ }^{41}$ The biopsy samples showed no significant differences between both sides. Wiltfang carried out a study with TCP on its own, or TCP + PRP, observing new bone formation that was $10 \%$ higher in the group in which PRP had been added. ${ }^{42}$ However, they were unable to demonstrate that the resorption/substitution rate with TCP was superior. Rodriguez et a ${ }^{43}$ presented 24 sinus augmentations in 15 patients with demineralised bovine bone and PRP, with no control group. With a single biopsy they observed an implant integration rate of $92 \%$ and they concluded that by adding PRP implants could be loaded earlier (4 months). In another study with biopsies on sinus augmentation with "bone substitutes" and PRP, a significant improvement was not noticed in sinus bone density. Kassolis used PRP with an allograft of freeze-dried bone for sinus augmentation in 36 


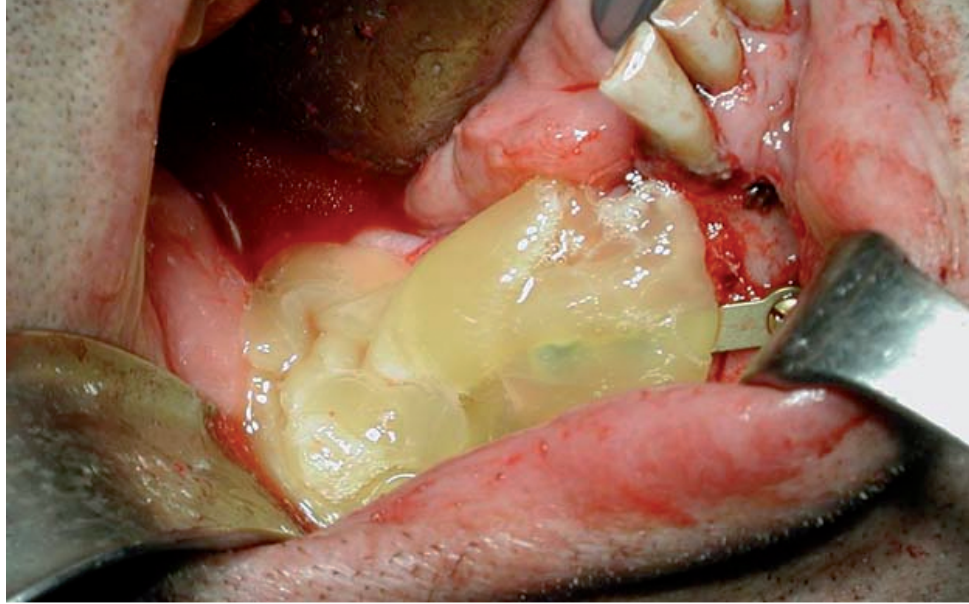

Figura 5. Injerto de cresta iliaca fijado con miniplacas y cubierto con membrana biológica de PRP.

Figure 5. Iliac crest graft fixed with miniplates and covered with biological PRP membrane.

Della Valle y cols., ${ }^{25}$ aplicaron gel de PRP en 40 pacientes sometidos a cirugía oral y anticoagulados por presentar valvulopatía de base: $5 \%$ presentaron complicaciones hemorrágicas y el $40 \%$ sangrado leve que se trató con medidas hemostáticas locales.

\section{Aplicaciones en periodoncia}

Las aplicaciones en periodoncia son básicamente de carácter clínico, aunque existen algunos trabajos de investigación en ciencias básicas. Okuda y Kawase demuestran nuevamente la elevada concentración de PDGF y TGF-beta en el PRP, observando un estímulo en la síntesis de ADN en los fibroblastos gingivales y en células del ligamento periodontal, así como su capacidad reguladora de la síntesis de colágeno en la matriz extracelular. ${ }^{26-27}$

De Obarrio incorpora el PRP a un aloinjerto de hueso y combinado con técnicas de regeneración tisular guiada (RTG) para tratar defectos intraóseos, observando una ganancia significativa en la inserción clínica y en el relleno óseo en los controles a los 2 años. ${ }^{28}$

Otros varios estudios han utilizado el PRP o el gel de fibrina en el manejo de defectos de recesión gingival, ${ }^{29-32}$ aisladamente o en combinación con diferentes técnicas de regeneración ósea guiada y distintos biomateriales. Los propios autores sugieren que son necesarios nuevos estudios para dilucidar el papel que desempeña cada componente en estas terapias combinadas.

\section{Aplicaciones en la elevación de seno}

Las aplicaciones del PRP en la elevación de seno, derivan de su efecto adhesivo sobre el material injertado. No se ha podido demostrar de forma fehaciente que posea un efecto osteoinductor intrínseco sobre los biomateriales síntéticos. La literatura recoge unas pocas series, que incluyen sobre todo el "How I do it?", pero no unos resultados consistentes a largo plazo. $33-37$ patients, observing in the biopsies that at 12 months there was bone formation around the allografts with no signs of inflammation. 45

\section{Application as a tissue adhesive}

One of the applications, in which there is general unanimity, is in its use as a biological adhesive. It has been used as a cohesive in bone grafts or particulate biomaterial, such as biological membranes or in a spray form in order to increase the adhesiveness of cutaneous or mucosal flaps to the receptor bed. Matras in 1982 described these fibrin adhesives as products with a capacity for tissue sealing and hemostasis, and for promoting tissue healing. ${ }^{46}$ It appears to act efficiently as a biological membrane.

\section{Application in soft tissue surgery}

PRP has been used in aesthetic surgery of the face since 1998, as a tissue adhesive in order to encourage and modulate healing in cutaneous flap reattachments. It has been used in rhytidectomy and blepharoplasty [procedures] and in other flap surgery, as well as in "laser resurfacing". The authors refer improved wound healing, and the elimination of dead space, eliminating the need to use aspiration drainage, or of using cutaneous sutures.2,49-51 Clinical comparisons that have not been objectively contrasted refer fewer edemas during the first 72 hours, which in turn leads to less pain in the immediate postoperative period. ${ }^{2}$ The incision lines show less erythema and inflammation and healing takes place faster than in the control [groups]. Marx in a study that was observational, histopathological and morphometric, observed that skin donor sites treated with PRP showed better wound healing, faster epithelization, greater skin thickness and less pain and discomfort when compared with the control [group]. ${ }^{52}$

Man used PRP in 20 patients that underwent aesthetic surgery including facelifts and breast surgery, observing improved hemostasis when PRP was used and fibrin gel. ${ }^{49}$

In $2003^{51} \mathrm{Hom}$ and Manivel presented a successfully treated cutaneous neck ulcer that had been present for 12 years, which was treated with recombinant human plateletderived growth factor-BB (Becaplermin), [gel], meaning that the indications for this product can be widened, and that its use is not restricted to the chronic ulcers of the extremities of diabetics.

\section{Application in Traumatology and Orthopedics}

Again we must insist on the importance of differentiating between the functions carried out by growth factors and those that are carried out by platelet-rich plasma. In the cur- 


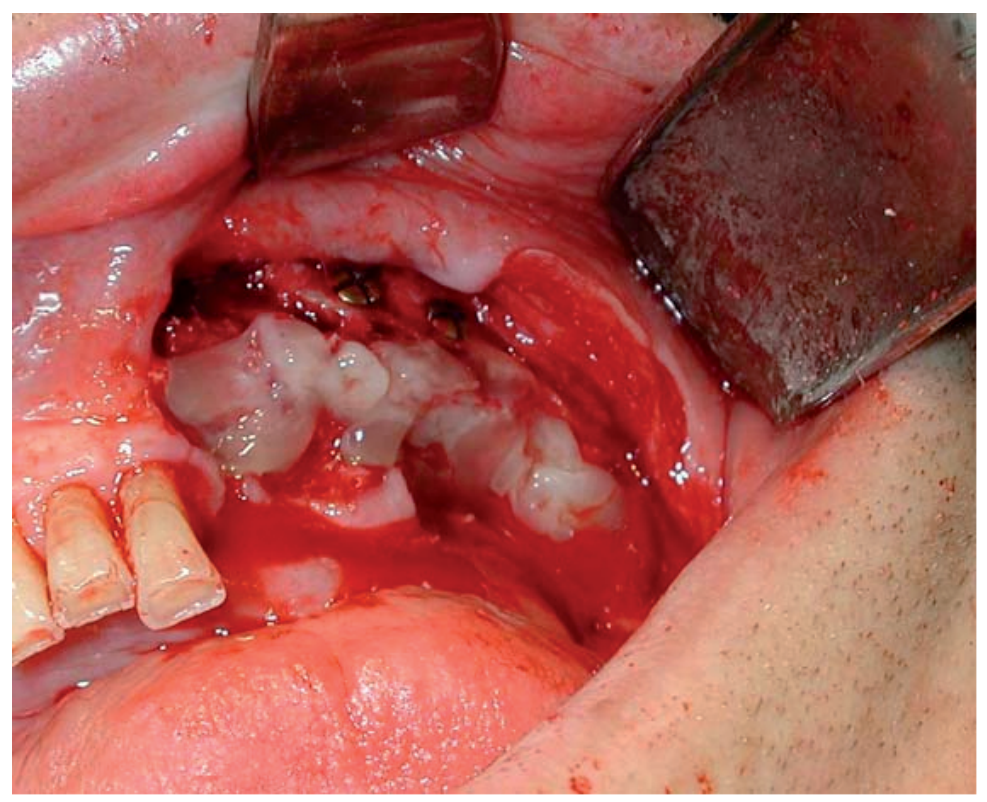

Figura 6. Injerto de cresta iliaca fijado con tornillos de osteosintesis Y cubierto con membrana biológica de PRP.

Figure 6. Iliac crest graft fixed with osteosynthesis screws and covered with biological PRP membrane.

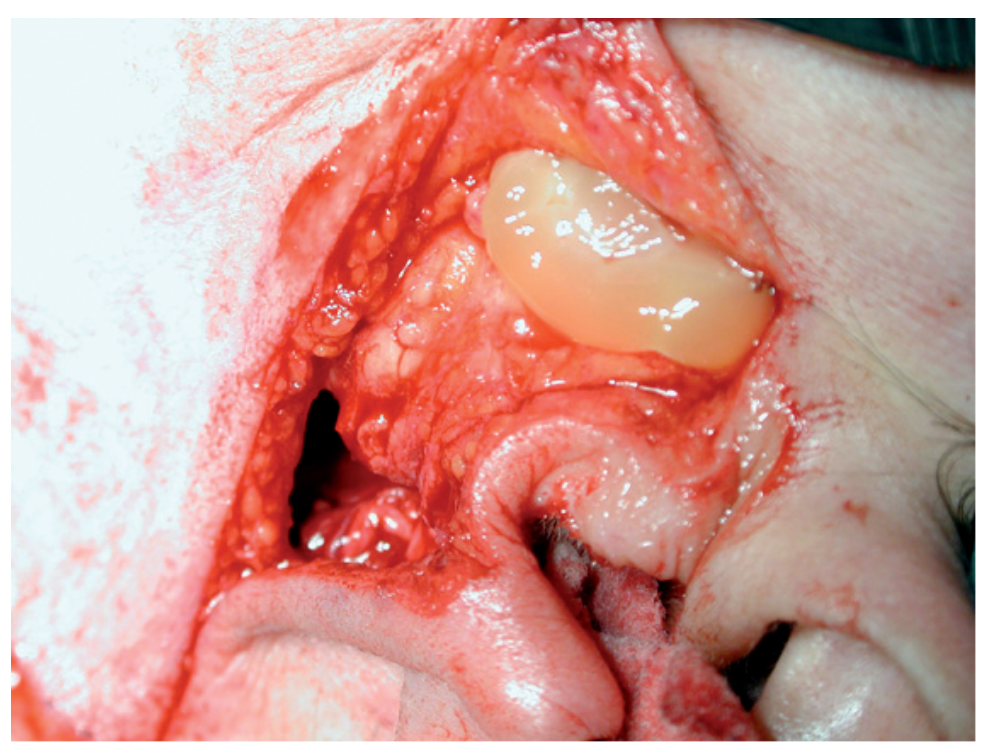

Figura 7. PRP en lecho de parotidectomía.

Figure 7. PRP on parotidectomy bed.

Wallace y Froum en 2003 presentan una revisión sistematizada de la literatura referente a la supervivencia de implantes en pacientes sometidos a una elevación de seno. No encontraron datos suficientes para recomendar el empleo de plasma rico en plaquetas en las elevaciones de seno. ${ }^{38}$

En las elevaciones de seno con hueso autogéno y PRP, Jakse y cols., observaron una mejora del 3-4\% en la formación de hueso en un estudio sobre 12 ovejas. Esta diferencia se consideró clinicamente no significativa y afirmaron que "el PRP tenía una capa- rent literature there is no scientific evidence that shows the supposed acceleration in fracture healing. There are reports on its application in muscle and tendon lesions, and its use in arthroscopic surgery, but these deal with preliminary clinical studies with no long-term follow-up. ${ }^{53}$ In facial osteotomies there are several anecdotal references on the use of PRP with beta-tricalcium phosphate for the management of severe atrophy of the upper maxilla. ${ }^{54}$

\section{Conclusions}

The enthusiasm generated in the media by the appearance of PRP as a biological procedure for bone regeneration does not appear to be accompanied by conclusive investigation results. A critical revision of the literature that exists on PRP and its clinical application allows drawing a series of conclusions that can be resumed in the following way. $55-57$

1. There are many articles on the possible skeletal applications of PRP, but there is no solid scientific evidence as to its efficiency in bone generation.

2. There are no experimental studies on the application of PRP in humans that indicate its advantages.

3. The clinical studies that exist are limited to just a few cases: in general these are uncontrolled clinical studies, with no success parameters, nor control group.

4. It efficiency has been suggested in a series of aspects that facilitate surgery such as the reduction of intra- and postoperative bleeding, faster soft-tissue healing with reduced inflammatory reaction, and greater initial stability of the tissue grafted at the receptor site as a result of its properties as a tissue adhesive.

In short, we are able to affirm that PRP is a promising tissue-engineering product, with no side effects having been described, and that it gives the professional [using it] surgical advantages that can justify its use. However, with current scientific evidence, it would be risky to affirm that by using PRP the acceleration of bone regeneration is a reality. 
cidad regeneradora de baja potencia". En un estudio sobre 21 conejos sometidos a un sinus lift con cresta ilíaca, Butterfield obtuvo resultados semejantes, ${ }^{39}$ concluyendo que no podían encontrar efecto estimulante del PRP sobre los injertos de hueso autógeno.

En elevaciones de seno con hueso bovino desmineralizado y PRP, Fürsts sobre 12 cerdos enanos concluyó que la combinación de PRP con otros biomateriales no era demostrablemente mejor que el PRP solo. ${ }^{40}$

También existen varios estudios de elevaciones de hueso con biomateriales en humanos. Froum efectuó un estudio en 3 pacientes efectuando una elevación de seno bilateral (Hueso bovino desmineralizado versus Hueso bovino desmineralizado+PRP). ${ }^{41}$ Las muestras biópsicas no observaron diferencias significativas entre ambos lados. Wiltfang efectuó un estudio con TCP solo, o TCP+PRP, observando una neoformación ósea un $10 \%$ superior en el grupo con adición de PRP, 42 no pudiendo demostrar sin embargo que la tasa de reabsorción/sustitución del TCP fuera superior. Rodríguez et al ${ }^{43}$ presentaron 24 elevaciones de seno en 15 pacientes con hueso bovino desmineralizado y PRP, sin grupo control. En una única biopsia, observaron una tasa de integración de los implantes del 92\%, y concluyeron que la adición del PRP permitiría una carga más precoz de los implantes (4 meses) En otro estudio con biopsia sobre elevaciones de seno con "sustitutos óseos" y PRP, no se observó una mejoría significativa en la densidad ósea del seno. Kassolis utiliza PRP con un aloinjerto de hueso liofilizado para la elevación de seno en 36 pacientes, observando en las biopsias a los 12 meses la formación de hueso alrededor de los aloinjertos sin signos de inflamación. ${ }^{45}$

\section{Aplicaciones como adhesivo tisular}

Una de las aplicaciones en las que existe una unanimidad general sobre el PRP, es en su utilidad como adhesivo biológico. ${ }^{7}$ Se ha utilizado para cohesionar injertos óseos o biomateriales particulados, como membrana biólogica o en forma de spray para aumentar la adhesividad de colgajos cutáneos o mucosos al lecho receptor. Matras en 1982 describía estos adhesivos de fibrina como productos con la capacidad de sellado tisular, hemostasia y promoción de la curación tisular. ${ }^{46}$ Parece actuar eficazmente como membrana biológica. ${ }^{47-48}$

\section{Aplicaciones en cirugía de los tejidos blandos}

EI PRP ha sido utilizado en cirugía estética de la cara desde 1998, como adhesivo tisular para favorecer y modular la curación en los colgajos cutáneos repuestos. Se ha utilizado en ritidectomías, blefaroplastias y en otras cirugías de colgajo, así como tras el "laser resurfacing". Los autores hablan de una mejor curación de las heridas, de la eliminación de espacios muertos, obviando así la nece- sidad de utilizar drenajes aspirativos, o de emplear suturas cutáneas. ${ }^{2,49-51}$ Comparaciones clínicas no objetivadas de otra forma hablan de un menor edema en las primeras 72 horas, que a su vez conduce a menos dolor en el postoperatorio inmediato. ${ }^{2}$ Las líneas de incisión presentan menos eritema e inflamación y una curación más rápida que los controles. Marx en un estudio observacional, histopatológico y morfométrico observó que las zonas de piel dadoras tratadas con PRP mostraban una mejor maduración de la herida, epitelización más rápida, mayor grosor cutáneo y menos dolor e incomodidad que cuando se comparó con los controles. ${ }^{52}$

Man utilizó PRP en 20 pacientes sometidos a cirugía estética incluyendo estiramientos y cirugía de mama observando una mejor hemostasia cuando se utilizaba PRP y gel de fibrina. ${ }^{49}$

Hom y Manivel, 51 presentan en 2003 el tratamiento con éxito de una úlcera cutanea cervical de 12 años de evolución tratada con factor de crecimiento recombinante humano derivado de plaquetas BB (Becaplermina), ampliando así las indicaciones de este producto más allá de las úlceras crónicas de diabéticos en extremidades.

\section{Aplicaciones en traumatología y ortopedia}

Nuevamente, insistimos en la importancia de diferenciar entre las funciones que desempeñan los factores de crecimiento, y las que realiza el plasma rico en plaquetas. En la literatura actual no se encuentra ninguna evidencia científica que demuestre la supuesta aceleración de la curación de las fracturas. Existen informes sobre su aplicación en lesiones musculares, tendinosas, o en su empleo en cirugía artroscópica, pero se tratan de estudios clinicos preliminares sin seguimientos a largo plazo. ${ }^{33}$ En osteotomías faciales existen notas anecdóticas del empleo de PRP con fosfato beta tricálcico para el manejo de una atrofia severa del maxilar superior. ${ }^{54}$

\section{Conclusiones}

El entusiasmo mediático generado por la aparición de PRP como procedimiento biológico de regeneración ósea no parece acompañarse de unos resultados de investigación concluyentes, Una revisión crítica de la literatura existente sobre el PRP y sus aplicaciones clínicas permite extraer una serie de conclusiones que se pueden resumir de la siguiente forma: ${ }^{55-57}$

1. Existen muchos artículos sobre las posibles aplicaciones esqueléticas del PRP, sin que existan evidencias científicas sólidas sobre su eficacia en la regeneración ósea.

2. No existen estudios experimentales sobre la aplicación de PRP en humanos que demuestren sus beneficios.

3. Los estudios clínicos existentes se limitan a unos pocos 
casos; en general se trata de estudios clínicos no controlados, sin parámetros de éxito, ni grupo control.

4. Se ha sugerido su eficacia en una serie de aspectos que facilitan la cirugía como son la disminución del sangrado intra y postoperatorio, una cicatrización más rápida de los tejidos blandos con una menor reacción inflamatoria, y una mejor estabilidad inicial del tejido injertado en el área receptora debido a sus propiedades de adhesivo tisular.

En resumen, podemos afirmar que el PRP es un prometedor producto de ingeniería tisular, del que no se han descrito efectos secundarios, y que ofrece al profesional unos beneficios quirúrgicos que pueden justificar su empleo. Sin embargo, con las evidencias cientificas actuales, es aventurado afirmar que con el PRP la aceleración de la regeneración ósea sea una realidad.

\section{Bibliografía}

1. Yao E, Eriksson E. Gene therapy in wound repair and regeneration. Wound Repair Regener 2000;8:443-51.

2. Adler SC, Kent KJ. Enhancing wound healing with growth factors. Facial Plast Surg Clin North Am 2002;10:129-46.

3. Weibrich G, Kleis WK, Hafner G. Growth factors levels in the platelet rich plasma produced by two different methods: curasan type PRP kit versus PCSS PRP system. Int J Oral Maxillofacial Implants 2002;17:18490.

4. Appel TR, Pötzsch B, Muller J, von Linden J], Berge SJ, Reich RH. Comparison of three different preparations of platelet concentrates for growth factor enrichments. Clin Oral Implants Res 2002;13:522-8.

5. Weibrich G, Kleis WK. Curasan PRP kit vs PCSS PRP system. Collection efficiency and platelet counts of two different methods for the preparation of platelet rich plasma. Clin Oral Implants Res 2002;13:43743.

6. Tayapongsak P, O'Brien DA, Monteiro CB. Autologous fibrin adhesive in mandibular reconstruction with particulate cancellous bone and marrow. J Oral Maxillofac Surg 1994;52:161-6.

7. Whitman DH, Berry RL. Green DM. Platelet gel: an autologous alternative to fibrin glue with applications in oral and maxillofacial surgery. J Oral Maxillofac Surg 1997;55:1294-8.

8. Marx RE, Carlson ER, Eichstaedt, y cols. Platelet rich plasma: growth factor enhancement for bone grafts. Oral Surg, Oral Med, Oral Pathol, Oral Radiol Endod 1998; 85:638-46.

9. Anitua Aldecoa E. Un Nuevo Enfoque en la Regeneración Ósea. Aldecoa Ed. Vitoria 2000.

10. Yazawa, y cols. Basic studies on the clinical applications of platelet rich plasma. Cell Transplant 2003;12:509-18.

11. Fennis JPM, StoelingaPJW. Jansen JA. Mandibular reconstruction: a clinical and radiographical animal study on the use of autogenous scaffolds and platelet rich plasma. Int J Oral Maxillofac Surg 2002;31:2816.

12. Fennis JPM, Stoelinga PJW. Jansen JA. Mandibular reconstruction: an histological and histomorphometric study on the use of autogenous scaffolds, particulate corticocancellous bone grafts and platelet rich plasma in goats. Int J Oral Maxillofac Surg 2004;33:48-55.
13. Aghaloo TL, Moy PK, Freymiller EG. Investigation of platelet rich plasma in rabbit cranial defects: a pilot study. J Oral Maxillofac Surg 2002;60:1176-81.

14. Aghaloo TL, Moy PK, Freymiller EG. Evaluation of platelet rich plasma in combination with anorganic bovine bone in the rabbit cranium: a pilot study. Int J Oral Maxillofac Implants 2004;19:59-65.

15. Choi BH, Im CJ, Huh JY, Suh JJ, Lee SH. Effect of platelet rich plasma on bone regeneration in autogenous bone graft. Int J Oral Maxillofac Surg 2004;33:56-9.

16. Kim SG, Kim WK, Park JC, Kim HJ. A comparative study of osseointegration of Avana implants in a demineralized freeze-dried bone alone or with platelet rich plasma. J Oral Maxillofac Surg 2002;60:1018-25.

17. Kim SG, Chung CH, KimYK, Park JC, Lim SC. Use of particulate dentin-plaster of Paris combination with/without platelet rich plasma in the treatment of bony defects around implants. Int J Oral Maxillofac Implants 2002; 17:86-94.

18. Roldan JC, Jepsen S, Miller J, Freitag S, Rueger DC, Acil Y, Terheyden $\mathrm{H}$. Bone formation in the presence of platelet rich plasma versus bone morphogenetic protein 7. Bone 2004;34:80-90.

19. Schlegel KA, Kloss FR, Kessler P, Schultze-Mosgau S, Nkenke E, Wiltfang J. Bone conditioning to enhance implant osseointegration: an experimental study in pigs. Int J Oral Maxillofac Implants 2003;18:50511.

20. Zechner W, Tangl S, Tepper G, Furst G, Bernhart T, Haas R, Mailath $\mathrm{G}$, Watzek G. Influence of platelet rich plasma on osseous healing of dental implants: a histologic and histomorphometric study in minipigs. Int J Oral Maxillofac Implants 2003;18:15-22.

21. Arpornmaeklong P, Kochel M, Depprich R, Kübler NR; Würzler KK: Influence of platelet rich plasma on osteogenic differentiation of rat bone stromal cells. An in vivo study. Int J Oral Maxillofac Surg 2004;33: 60-70.

22. Anitua E. Plasma Rich in Growth Factors: preliminary results of use in the preparation of future site for implants. Int J Oral Maxillofac Implants 1999;14:529-35.

23. Anitua $E$. The use of plasma rich growth factors in oral surgery. Pract Proced Esthet Dent 2001;13:487-93.

24. Mancuso, Bennion, Hull. Platelet rich plasma: a preliminary report in routine impacted third molar surgery and the prevention of alveolar osteitis. J Oral Maxillofac Surg 2003;61(8 suppl):36.

25. Della Valle A, Sammartino G, Marenzi G, Tia M, Espedito A, Ferrari F, Lo Muzio L. Prevention of postoperative bleeding in anticoagulated patients undergoing oral surgery: use of platelet rich plasma. J Oral Maxillofac Surg 2003;61:1275-8.

26. Okuda K, Kawase T, Momose M, Murata M, Saito Y, Suzuki H, Wollf LF, Platelet rich plasma contains high levels of platelet derived growth factors and transforming growth factor beta and modulates the proliferation of periodontal related cells in vitro. J Periodontal 2003;74:849-57.

27. Kawase T, Okuda K, Wolff LF, Yoshie H, Platelet rich plasma derived fibrin clot formation stimulates collagen synthesis in periodontal ligament and osteoblastic cells in vitro. J Periodontol 2003;74:858-64.

28. De Obarrio JJ, Aruz Dutari JI, Chamberlain TM, Croston A. The use of autologous growth factors in periodontal surgical therapy: platelet gel biotechnology case reports. Int J Periodontics Restorative Dent 200;20:487-97.

29. Petrungaro PS. Using platelet rich plasma to accelerate soft tissue 
maturation in esthetic periodontal surgery. Compend Contin Educ Dent 2001;22:729-36.

30. Lekovic V, Camargo PM, Weinlaender M, Vasilic N, Kenney EB. Comparison of platelet rich plasma, bovinous porous bone mineral and guided tissue regeneration versus platelet rich plasma and bovine porous bone mineral in the treatment of intrabony defects: a reentry study. J Periodontol 2002;73:198-205.

31. Camargo PM, Lekovic V, Weinlander M, Vasilic N, Madzarevic M, Kenney EB. Platelet rich plasma and bovine porous bone mineral combined with guided tissue regeneration in the treatment of bony defects in humans. J Periodontol Res 2002;37:300-6.

32. Dugrillon A, Eichler H, Kern S, Kluter H. Autologous concentrated platelet rich plasma for local application in bone regeneration. Int J Oral Maxillofac Surg 2002;31:615-9.

33. Maiorana C, Sommariva L, Brivio P, Sigurta D, Santoro F. Maxillary sinus augmentation with anorganic bone (Bio-Oss) and autologous platelet rich-plasma: preliminary clinical and histological evaluation. Int J Periodontics Restorative Dent 2003;23:227-35.

34. Moro G, Casini V, Bastieri A. Use of platelet rich plasma in major maxiIlary sinus augmentation. Minerva Stomatol 2003;52:267-71.

35. Jakse N, Gilli R, Berghold A, Lorenzoni M, Eskici A, Haas R, Perti C. Influence of PRP on autogenous sinus grafts. Clin Oral Implant Res 2003; 14:578-83.

36. Pacifici L, Casella F, Ripari M. Lifting of the maxillary sinus: complementary use of platelet rich plasma: autologous bone deprotenised bovine bone: case report. Minerva Stomatol 2003;52:471-8.

37. Politi M, Robiony M. Bone Biological Box: an evolution of the sinus graft. J Oral Maxilllofac Surg 2003;61:1108-11.

38. Wallace SS, Froum SJ. Effects of maxillary sinus augmentation on the survival of endosseous dental implants: as systematic review. Ann Periodontol 2003;8:328-343.

39. Butterfield KJ, Bennet J, Gronowitz G. Effect of platelet rich plasma with autogenous bone grafts for sinus augmentation in a rabbit model. J Oral Maxillofac Surg 2003;61:97(suppl).

40. Furst G, Gruber R, Tang S, Zechner W, Haas R, Mailath G, Sanroman $F$, Watzek $G$. Sinus grafting with autogenous platelet rich plasma and bovine hidroxiapatite: a histomorphometric study in minipigs. Clin Oral Implant Res 2003;14:500-8.

41. Froum SJ, Wallace SS, Tarnow DP, Cho SC. Effect of platelet rich plasma on bone growth and osseointegration in human maxillary sinus grafts: 3 bilateral case reports. Int J Periodontics Restorative Dent 2002;22:45-53.

42. Wiltfang J, Schlegel KA, Schultze-Mosgau S, Nkenke E, Zimmerman $\mathrm{R}$, Kessler P. Sinus floor augmentation with beta-tricalciumphospha- te: does platelet rich plasma promote its osseous integration and degradation? Clin Oral Implants Res 2003;14:213-8.

43. Rodriguez A, Anastassov GE, LeeH, Buchbinder D, Wettan H. Maxillary sinus augmentation with deproteinated bovine bone and platelet rich plasma with simultaneous insertion of endosseous implants. J Oral Maxillofac Surg 2003;61:157-63.

44. Danesh-Meyer MJ, Filstein MR, Shanaman SR. Histological evaluation of sinus augmentation using platelet rich plasma (PRP): a case series. Int J Acad Perodontol 2001;3:48-56.

45. Kassolis JD, Rosen PS, Reynolds Ma. Alveolar ridge and sinus augmentation utilizing platelet rich plasma in combination with freezedried bone allograft: case series. J Periodontol 2000;71:1654-61.

46. Matras $\mathrm{H}$. The use of fibrin glue in oral and maxilofacial surgery. J Oral Maxillofac Surg 1981;40:617.

47. Soffer E, Ouhayoun JP, Anagnostou F. Fibrin sealants and platelet preparations in bone and periodontal healing. Oral Surg Oral Med Oral Pathol Oral Radiol Endod 2003;95:421-528.

48. Thorn JJ, Sorensen H, Weis-Fogh U, Andersen M. Autologous fibrin glue with growth factors in reconstructive maxillofacial surgery. Int J Oral Maxillofac Surg 2004;33:95-100.

49. Man D, Plasker $H$, Winland Brown JE. The use of autologous platelet rich plasma (platelet gel) and autologous platelet poor plasma (fibrin glue) in cosmetic surgery. Plast Reconst Surg 2001;107:238-23.

50. Marx RE y cols. Healing enhancement of skin donor sites with platelet rich plasma. J Oral Maxillofac Surg 2000;58:301-2.

51. Hom DH, Manivel JC. Promoting healing with recombinant human platelet derived growth factors-BB in a previously irradiated problem wound. Laryngoscope 2002;113:1566-71.

52. Marx RE. Healing enhancement of skin donor sites with platelet rich plasma. J Oral Maxillofac Surg 2000;58:45-50.

53. Garcia Esteo FJ, Gimeno ML, Bujan M. Factores de crecimiento en cirugía ortopédica y traumatología. SECOT: Cursos de actualización del 40 Congreso Nacional pp 2004;60-79.

54. Foitzik C, Strauss H Lefort1 osteotomy in atrophied maxilla and bone regeneration with pure phase beta tricalcium phosptae and PRP. Implant Dent 2003;12:132-9.

55. Sanchez AR, Sheridan PJ, Kupp LI. Is platelet rich plasma the perfect enhancement factor? A current review. Int J Oral Maxillofac Implants 2003; 18:93-103.

56. Schliephake H. Bone growth factors in maxillofacial skeletal reconstruction. Int J Oral Maxillofac Surg 2002;31:469-84.

57. Freymiller EG, Aghaloo T. Platelet rich plasma: ready or not. J Oral Maxillofac Surg 2004;62:484-8. 